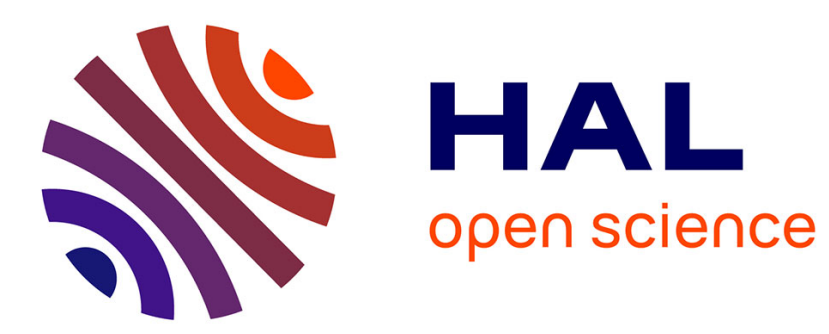

\title{
Heart rate recovery improves after exercise in water when compared with on land
}

\author{
Alain Boussuges, Pascal Rossi, Laurent Poirette, Olivier Gavarry
}

\section{To cite this version:}

Alain Boussuges, Pascal Rossi, Laurent Poirette, Olivier Gavarry. Heart rate recovery improves after exercise in water when compared with on land. Clinical Physiology and Functional Imaging, 2018, 38 (4), pp.721-724. 10.1111/cpf.12464 . hal-01760670

\section{HAL Id: hal-01760670 \\ https://hal.science/hal-01760670}

Submitted on 23 May 2018

HAL is a multi-disciplinary open access archive for the deposit and dissemination of scientific research documents, whether they are published or not. The documents may come from teaching and research institutions in France or abroad, or from public or private research centers.
L'archive ouverte pluridisciplinaire HAL, est destinée au dépôt et à la diffusion de documents scientifiques de niveau recherche, publiés ou non, émanant des établissements d'enseignement et de recherche français ou étrangers, des laboratoires publics ou privés. 
Clin Physiol Funct Imaging. 2017 Aug 10. doi: 10.1111/cpf.12464. [Epub ahead of print]

\section{Heart rate recovery improves after exercise in water when compared with on land.}

Boussuges A1,2, Rossi P3,4, Poirette L5, Gavarry O6.

\section{Author information}

1

UMR MD2, Aix Marseille University (AMU), Marseille, France.

2

French Armed Forces Biomedical Research Institute (IRBA), Brétigny sur Orge, France.

3

Internal Medicine Department, Hôpital Nord, Assistance Publique-Hôpitaux de Marseille (AP-HM), Marseille, France.

4

UMR INSERM 608, Vascular research center of Marseille, Aix Marseille University, Marseille, France.

5

Léon Bérard Hospital, Cardiac Rehabilitation center, Hyères, France.

6

HandiBio Laboratory, Toulon University, La Garde, France.

\section{Abstract}

\section{BACKGROUND:}

Water immersion has demonstrated its effectiveness in the recovery process after exercise. This study presents for the first time the impact of water immersion on heart rate recovery after low-intensity cycle exercise.

\section{METHODS:}

Sixteen male volunteers were involved in the study. The experiment consisted of two cycling exercises: $1 \mathrm{~h}$ in ambient air and $1 \mathrm{~h}$ in water (temperature: $32 \pm 0.2^{\circ} \mathrm{C}$ ). The exercise intensity was individually prescribed to elicit around $35 \%-40 \%$ of VO2 peak for both conditions. Heart rate recovery was analysed according to recognized methods, such as the differences between heart rate at exercise completion and within the 2 min recovery period.

\section{RESULTS:}

Although the two exercises were performed both at same energy expenditure and heart rate, the indexes used to assess the fast and slow decay of the heart rate recovery were significantly shortened after exercise in water.

\section{CONCLUSION:}

The results of the present study suggest that cycling in thermoneutral water decreases the cardiac work after exercise when compared with cycling on land.

(C) 2017 Scandinavian Society of Clinical Physiology and Nuclear Medicine. Published 
by John Wiley \& Sons Ltd.

KEYWORDS:

cardiac function; cycling; oxygen uptake; recovery; thermoneutrality

PMID: 28795483 DOI: 10.1111/cpf.12464 